Original Paper

\title{
Pengembangan Profil Produk Manisan Cabai dan Business Model Canvas Di Desa Lenek Duren
}

\author{
I Wayan Merta ${ }^{1 *}$, M. Khaerul Anwar', Rusdi Bastian Ilham ${ }^{1}$ \\ ${ }^{1}$ Program Studi Pendidikan Biologi Fakultas Keguruan dan Ilmu Pendidikan, Universitas Mataram
}

*Corresponding Author: I Wayan Merta, Program Studi Pendidikan Biologi Fakultas Keguruan dan Ilmu Pendidikan, Universitas Mataram, Indonesia;

Email: wayanmerta.fkip@unram.ac.id

\begin{abstract}
Abstrak: Tanaman cabai (Capsicum annuum L.) merupakan salah satu komoditas hortikultura yang banyak dibudidayakan oleh masyarakat Indonesia. Desa Lenek Duren, Kecamatan Lenek, Kabupaten Lombok Timur memiliki hasil pertanian yang melimpah. Salah satu hasil pertanian yang terkenal di desa Lenek Duren adalah cabai. Permasalahannya tanaman cabai bersifat musiman sehingga sangat susah untuk mendapatkannya apabila belum masa panen sedangkan ketika musim panen tiba, cabai banyak ditemukan di pasaran dengan harga yang sangat murah bahkan tidak bernilai jika terlewat melimpah hasil panennya sehingga menyebabkan nilai jual dari menjadi tidak stabil yang dapat merugikan para petani cabai di desa tersebut. Salah satu solusi yang dapat dilakukan untuk mengatasi permasalahan adalah dengan memproduksinya menjadi manisan cabai. Untuk menghasilkan produk manisan cabai perlu melalui beberapa tahapan, antara lain sortasi \& pembersihan, pembelahan, perendaman air garam, perendaman air gula, pengeringan, pengemasan. Setelah adanya produk, tentunya dibutuhkan suatu metode untuk memasarkan produk tersebut agar dapat menghasilkan keuntungan secara ekonomis terhadap masyarakat khususnya para petani cabai di desa lenek duren. Berdasarkan analisa yang dilakukan business model yang cocok digunakan adalah business model canvas karena business model canvas merupakan cara yang dapat membantu peneliti dalam merumuskan model bisnis yang inovatif bagi mitra dalam rangka mencapai tujuan-tujuan pada bersama.
\end{abstract}

Kata Kunci: Cabai; Manisan; Business Model Canvas

\section{Pendahuluan}

Tanaman cabai (Capsicum annuum L.) merupakan salah satu komoditas hortikultura yang banyak dibudidayakan oleh masyarakat Indonesia. Tanaman ini bernilai ekonomi tinggi dan mempunyai daya adaptasi yang cukup luas sehingga dapat dibudidayakan di berbagai ekosistem yang berbeda.

Cabai merupakan salah satu komoditi sayuran yang paling diminati masyarakat Indonesia setelah bawang merah dan tanaman palawija (BPS 2012). Pada tahun 2012 produksi cabai di Indonesia mencapai 1.650.831 ton. Hal ini dikarenakan cabai adalah tanaman yang mudah beradaptasi, mudah tumbuh dan berkembang sehingga banyak petani Indonesia yang melakukan budidaya tanaman cabai.
Desa Lenek Duren, Kecamatan Lenek, Kabupaten Lombok Timur terkenal dengan hasil pertaniannya. Salah satu hasil pertanian yang terkenal di desa Lenek Duren adalah cabai. Permasalahannya tanaman cabai bersifat musiman sehingga sangat susah untuk mendapatkannya apabila belum masa panen sedangkan ketika musim panen tiba, cabai banyak ditemukan di pasaran dengan harga yang sangat murah bahkan tidak bernilai jika terlewat melimpah hasil panennya sehingga menyebabkan nilai jual dari menjadi tidak stabil yang dapat merugikan para petani cabai di desa tersebut.

Permasalahan lainnya pada cabai adalah sifatnya yang cepat rusak atau tidak tahan lama. Cabai segar yang disimpan pada suhu kamar memiliki umur simpan yang pendek yaitu sekitar 3-5 hari. Cabai segar yang 
disimpan pada suhu kurang dari $10^{\circ} \mathrm{C}$ hanya mampu bertahan selama 7-10 hari. Oleh karena itu, kegiatan penanganan panen dan pascapanen merupakan salah satu mata rantai yang sangat penting. Teknik penanganan panen dan pascapanen yang baik akan menyebabkan umur simpan cabai merah menjadi lebih lama (Sembiring, 2009).

Cara yang dapat dilakukan antara lain proses pendinginan, penyimpanan pada udara kontrol atau pengolahan menjadi produk baru yaitu manisan cabai. Selama ini, tanaman cabai sudah terlalu banyak diolah sebagai bumbu masakan dan industri sauce sehingga pandangan ini menjadi alasan untuk mengembangkan produk olahan baru yaitu manisan cabai di masyarakat.

Di Nusa Tenggara Barat khususnya Desa Lenek Duren, Kecamatan Lenek, Kabupaten Lombok Timur produk manisan cabai adalah produk baru yang masih jarang diketahui masyarakat. Berdasarkan hal tersebut, terbentuk ide dasar untuk mengembangkan produk manisan cabai. Pengembangan produk inovatif ini didukung dengan ketersediaan bahan baku yang melimpah di desa tersebut. Produk manisan cabai diharapkan mampu menjadi produk baru yang memiliki daya jual tinggi, membuka pangsa pasar baru di industri pengolahan, dan

dapat memberi keuntungan terhadap masyarakat setempat secara ekonomi.

Menurut Osterwalder dan Pigneur (2012), business model canvas adalah sebuah bahasa yang sama untuk menggambarkan, memvisualisasikan, menilai, dan mengubah model bisnis pada suatu perusahaan. Business mode canvas juga dapat sebagai alat untuk mendeskripsikan, menganalisa, dan merancang model bisnis pada suatu perusahaan. Konsep business model canvas terdiri dari Sembilan elemen yaitu value propositions, customer segments, customer relationship, channels, key resources, key activities, key partnership, cost structure, dan revenue streams. Elemen tersebut dapat membantu dalam merumuskan model bisnis suatu perusahaan dan merancang ide model bisnis yang inovatif bagi perusahaan. (Osterwalder \& Pigneur, 2012).

Berikut ini adalah penjelasan The Nine Building Blocks Business Model Canvas:

\section{a. Customer Segments}

Blok bangunan segmen pelanggan menggambarkan sekelompok orang atau organisasi berbeda yang ingin dijangkau atau dilayani oleh perusahaan. Suatu perusahaan perlu memperhatikan pelanggannya, hal ini disebabkan karena pelanggan adalah inti dari semua model bisnis. Setelah itu, perusahaan dapat merancang model bisnis dengan pemahaman yang tepat mengenai kebutuhan spesifik pelanggan.

b. Value Propositions

Blok bangunan proposisi nilai menggambarkan gabungan antara produk dan layanan yang menciptakan nilai untuk segmen pelanggan spesifik. Value propositions (Proposisi nilai) merupakan salah satu alasan bagi pelanggan untuk beralih dari satu perusahaan ke perusahaan yang lain. Setiap proposisi nilai terdiri dari gabungan produk dan/atau jasa tertentu yang dapat melayani kebutuhan-kebutuhan dari segmen pelanggan yang spesifik. Sehingga proposisi niai merupakan kesatuan, atau gabungan dari manfaatmanfaat yang ditawarkan oleh perusahaan kepada pelanggan.

\section{c. Channels}

Blok bangungan saluran menggambarkan tentang bagaimana sebuah perusahaan berkomunikasi dengan segmen pelangganya dan menjangkau mereka untuk memberikan Value. Saluran komunikasi, distribusi, dan penjualan merupakan penghubung antara perusahaan dengan pelanggan

\section{d. Customer Relationships}

Blok bangunan hubungan pelanggan menggambarkan berbagai jenis hubungan yang dibangun perusahaan bersama segmen pelanggan yang spesifik. Hubungan pelanggan menjelaskan bahwa sebuah perusahaan harus menentukan jenis hubungan yang ingin dibangun bersama segmen pelangganya.

\section{e. Revenue Streams}

Blok bangunan arus pendapatan menggambarkan uang tunai yang dihasilkan oleh perusahaan dari masing-masing segmen pelanggan, bahwa biaya harus mengurangi pendapatan untuk menghasilkan pemasukan. Suatu model bisnis melibatkan dua jenis arus pendapatan yaitu pendapatan transaksi yang dihasilkan dari satu kali pembayaran oleh pelanggan dan pendapatan yang berkelanjutan atau bersifat berulang yang dihasilkan dengan memberikan proposisi nilai pada pelanggan maupun menyediakan dukungan pelanggan pasca pembelian. 


\section{f. Key Activities}

Blok bangunan aktivitas kunci menggambarkan hal-hal terpenting yang harus dilakukan oleh perusahaan agar model bisnisnya dapat bekerja sesuai dengan tujuan perusahaan. Setiap model bisnis membutuhkan sejumlah aktivias kunci, yaitu berupa tindakan-tindakan terpenting yang harus diambil oleh perusahaan agar dapat beroperasi dengan baik. Key activites dapat dikategorikan ke dalam produksi, pemecahan masalah, dan platform/jaringan berupa layanan dan promosi.

\section{g. Key Resources}

Blok bangunan sumber daya utama menggambarkan asset-asset terpenting yang diperlukan agar sebuah model bisnis dapat berfungsi. Setiap model bisnis memerlukan sumber daya utama. Sumber daya ini memungkinkan suatu perusahaan menciptakan dan menawarkan proposisi nilai, menjangkau pasar, mempertahankan hubungan dengan segmen pelanggan, dan memperoleh pendapatan. Sumber daya utama dapat berbentuk fisik, finansial, intelektual atau manusia.

\section{h. Key Partnership}

Blok bangunan kemitraan utama yang menggambarkan jarigan pemasok dan mitra yang membuat model bisnis suatu perusahaan dapat bekerja. Perusahaan membentuk kemitraan dengan berbagai alasan dan kemitraan menjadi landasan yang penting dari berbagai model bisnis. Perusahaan menciptakan kemitraan yang bertujuan untuk mengoptimalkan model bisnis, mengurangi risiko, atau memperoleh sumber daya mereka.

\section{i. Cost Structure}

Struktur biaya menggambarkan semua biaya yang dikeluarkan oleh perusahaan untuk mengeoperasikan sebuah model bisnis. Blok bangunan ini menjelaskan mengenai biaya-biaya terpenting yang muncul ketika suatu perusahaan mengoperasikan model bisnis tertentu. Perhitungan struktur biaya akan lebih mudah apabila sumber daya utama, aktivitas-aktivitas kunci dan kemitraan utama telah ditentukan.

Tujuan dari penelitian ini adalah mengembangkan profil produk manisan cabai untuk meningkatkan daya simpan cabai dan merancang pemodelan bisnis untuk menjaga stabilitas harga agar tidak merugikan para petani cabai di Desa Lenek Duren.

\section{Metode Pelaksanaan}

Jenis penelitian yang digunakan adalah deskriptif dengan menggunakan metode penelitian tindakan. Menurut Indrawati (2015) penelitian deskriptif dilakukan ketika peneliti sudah mengetahui faktor atau variabel untuk mengukur suatu objek atau bidang tetapi belum mengetahui hubungan antara faktor atau variabel tersebut (Indrawati, 2015). Penelitian deskriptif bertujuan untuk menggambarkan permasalahan sosial yang dijadikan sebagai objek penelitian.Penelitian tindakan adalah suatu bentuk penelitian refleksi-diri yang dilakukan oleh para partisipan dalam situasi sosial untuk memperbaiki praktek yang dilakukan sendiri (Dharma, 2009). Penelitian tindaka ini bertujuan untuk memperbaiki keadaan atau situasi dimana praktek tersebut dilaksanakan.

\section{Hasil dan Pembahasan}

Untuk menghasilkan produk manisan cabai perlu melalui beberapa tahapan, antara lain Sortasi \& Pembersihan, Pembelahan, Perendaman air garam, Perendaman air gula, Pengeringan, Pengemasan.

Berdasarkan Analisa yang dilakukan Business Model yang digunakan adalah business model canvas karena business model canvas merupakan cara yang dapat membantu peneliti dalam merumuskan model bisnis yang inovatif bagi mitra dalam rangka mencapai tujuan-tujuan pada bersama.

Desa Lenek Duren merupakan bagian wilayah dari Kecamatan Lenek, Kabupaten Lombok Timur, Provinsi NTB. Desa Lenek Duren saat ini terdiri dari 3 dusun yaitu Dusun Duren, Dusun Kekalian, dan Dusun Timba Ledang. Wilayah Desa Lenek Duren diperkirakan memiliki luas wilayah sekitar $225,13 \mathrm{ha} / \mathrm{m}^{2}$. Batas wilayah Desa Lenek Duren sebelah utara terdapat hutan tutupan Taman Nasional Gunung Rinjani (TNGR), sebelah selatan terdapat Desa Lenek Daya, sebelah barat terdapat Desa Pengadangan, dan sebelah timur terdapat Desa Toya.

Topografi Desa Desa Lenek Duren berada pada dataran tinggi/pegunungan dengan ketinggian $800 \mathrm{~m}$ diatas permukaan laut (mdpl). Curah 
hujannya adalah 2.853,90 pertahun, rata-rata 6 bulan per tahun. Suhu udara rata-ratanya adalah $30^{\circ} \mathrm{C}$ dengan kelembapan $25^{\circ} \mathrm{C}$. Topografinya adalah tanah berwarna kecoklatan, tekstur debuan dengan tingkat kemiringan $30^{\circ}$. Desa Lenek Duren memiliki luas wilayah $\pm 225,13 \mathrm{Ha}$ dimana luas wilayah menurut penggunaannya adalah $152,64 \mathrm{Ha}$ luas tanah perkebunan (perorangan), $47 \mathrm{Ha}$ luas tanah kering (38 $\mathrm{Ha}$ pekarangan dan $9 \mathrm{Ha}$ pemukiman), 25 Ha luas tanah sawah (tadah hujan), dan 0,49 luas fasilitas umum $(0,15$ Ha perkantoran pemerintah, 0,2 Ha tempat pemakaman umum, 0,06 $\mathrm{Ha}$ bangunan sekolah, dan $0,08 \mathrm{Ha}$ fasilitas pasar).Desa Lenek Duren dapat ditempuh selama 12 menit (menggunakan kendaraan bermotor) dengan jarak tempuh $7,5 \mathrm{~km}$ dari Ibu Kota Kecamatan (Lenek), selama 45 menit dengan jarak tempuh $25 \mathrm{~km}$ dan dari Ibu Kota Kabupaten (Selong), dan selama 2 jam dengan jarak tempuh 64 km dan dari Ibu Kota Provinsi (Mataram).

Potensi utama yang dimiliki oleh Desa Lenek Duren terdapat pada sektor pertanian dan perkebunan. Dengan luas wilayah mencapai 177,64 Ha (perkebunan 152,64 Ha dan Pertanian $25 \mathrm{Ha}$ ) yang didukung oleh tanah yang subur dan sumber mata air yang terus mengalir membuat desa lenek duren dapat memiliki produksi hasil perkebunan dan pertanian yang melimpah seperti alpukat, duren, jeruk, padi, cabai, ubi, dan masih banyak lagi. Sayangnya belum ada lembaga/mitra yang mengelola atau mendukung untuk meningkatakan nilai ekonomis dari hasil produksi perkebunan dan pertanian tersebut sehingga selama ini para pekebun dan petani hanya menjual hasil panennya kepada pengepul dengan harga pasaran yang tidak konsisten.

Tahapan proses pembuatan produk manisan cabai di desa lenek duren antara lain:

\section{a. Sortasi \& Pembersihan}

Proses ini meliputi pemilihan cabai yang berkualitas, memisahkan dengan bagian yang busuk, setelah itu dicuci sampai bersih, dan yang terakhir ditiriskan.

b. Pembelahan

Proses ini meliputi membelah cabai scara vertikal untuk mengeluarkan biji dan isi dalam cabai tanpa merusak bentuk dari kulit cabai tersebut.

c. Perendaman dalam larutan garam

Proses ini meliputi pembuatan larutan garam dengan cara memasukkan 50gr garam kedalam $750 \mathrm{ml}$ air putih kemudian diaduk hingga garamnya larut, setelah itu masukkan cabai ke dalam larutan untuk direndam selama 12 jam, dan yang terakhir ditiriskan. Perendaman ini bertujuan untuk menghilangkan rasa pedas pada cabai.

d. Perendaman dalam larutan gula

Proses ini meliputi pembuatan larutan gula dengan cara memanaskan $500 \mathrm{ml}$ air putih kemudian dimasukkan gula pasir dan diaduk hingga larut, setelah itu masukkan cabai ke dalam larutan untuk direndam selama 12 jam. Perendaman ini bertujuan untuk memberi rasa manis pada cabai, jika dirasa cabai belum menunjukkan rasa manis yang cukup maka proses ini bisa dilakukan lebih dari sekali.

e. Pengeringan

Proses ini dapat dilakukan dengan 2 cara yaitu menggunakan oven dan sinar matahari. Pengeringan menggunakan oven dapat dilakukan dengan mengatur suhu pada $45-50^{\circ} \mathrm{C}$ dan dikeringkan selam $15-18$ jam. Sedangkan pengeringan menggunakan sinar matahari memerlukan waktu yang tidak tentu tergantung pada daerah dan cuaca. Ketika dilakukan di kota mataram dibutuhkan waktu 2-3 hari (12jam/hari) untuk manisan cabai mencapai tekstur yang diinginkan, sedangkan di desa lenek duren yang merupakan dataran tinggi dibutuhkan waktu sekitar 4-6 hari (12jam/hari) untuk proses pengeringan.

f. Pengemasan

Proses ini meliputi penentuan bentuk kemasan yang digunakan dan membuat desain label produk. Produk manisan cabai desa lenek duren dikemas menggunakan plastic ziplock agar tidak terkontaminasi Produk ini memiliki label dengan nama MANCAB LDR yang merupakan singkatan dari "Manisan Cabai Lenek Duren".

Setelah dilakukan studi literatur, observasi, dan wawancara. Berikut adalah analisi dari penerapan Business Model Canvas di Desa Lenek Duren:

\section{a. Customer Segments}

Pada usaha produk manisan cabai, segmen pasar yang dipilih adalah ibu rumah tangga, remaja, dan anak-anak yang cenderung memiliki kebiasaan mengkonsumsi cemilan.

\section{b. Value Propositions}

Pada usaha manisan cabai, proposisi nilai produk yang diinginkan adalah produk manisan cabai tanpa menggunakan bahan pengawet dan kaya akan kandungan gizi. 
c. c. Channels

Channels usaha produk manisan ini adalah penjualan melalui retail dan promosi melalui foodgram ataupun newsgram.

d. d. Customer Relationships

Pada usaha produk manisan cabai ini hubungan pelanggan yang digunakan adalah mendapatkan konsumen melalui strategi promosi melalui media sosial, bazaar, selebaran, dan strategi pendekatan langsung ke konsumen (pasar, toko oleh-oleh dan pusat makanan).

e. Revenue Streams

Pada usaha produk manisan cabai arus pendapatan yang ditargetkan adalah penjualan langsung dan penjualan ke pedagang kecil maupun besar dan konsumen secara individu.

f. Key Activities

Aktivitas utama yang penting dalam pembuatan manisan cabai adalah produksi manisan cabai, membuat kemasan, pengenalan produk, pemasaran, dan promosi produk.

\section{g. Key Resources}

Sumber daya utama untuk usaha manisan ini adalah sumber daya fisik (fasilitas pribadi dan sarana produksi) dan marketing.

h. Key Partnership

Mitra utama yang diperlukan dalam usaha ini adalah petani lokal.

$i$. Cost Structure

Struktur biaya dalam usaha manisan cabai adalah biaya alat \& bahan (produksi, biaya distribusi tak langsung dan biaya distribusi langsung.

\section{Kesimpulan}

Manisan cabai adalah solusi yang tepat untuk mengatasi permasalahan pascapanen pada cabai merah di Desa Lenek Duren karena dapat memperpanjang umur simpan cabai dan menjaga stabilitas harga walaupun sedang dalam kondisi panen melimpah. Penelitian lebih lanjut diperlukan untuk mengetahui umur simpan manisan cabai secara pasti dengan menggunakan beberapa faktor seperti, waktu pengeringan optimal, suhu penyimpanan, bahan kemasan yang digunakan, dll. Selain itu, juga diperlukan penelitian untuk menghitung kurs keuntungan perbandingan penjualan cabai secara langsung dengan pasca produksi menjadi manisan cabai dan validasi dari
Business Model Canvas yang digunakan untuk pemodelan bisnis di Desa Lenek Duren, Kecamatan Lenek, Kabupaten Lombok timur, Nusa Tenggara Barat

\section{Daftar Pustaka}

Badan Pusat Statistik. 2012. Hasil Holtikultura Indonesia.

Osterwalder, A., \& Pigneur, Y. 2012. Business Model Generation: A Handbook for Visionaries, Game Changers, and Challengers. Jakarta: Elex Media Komputindo.

Sembiring, N. N. 2009. Pengaruh jenis bahan pengemas terhadap kualitas produk cabai merah (Capsicum annuum L.). Tesis. Pascasarjana Universitas Sumatera Utara, Medan

Indrawati, W. E. 2015. Pengaruh Konsentrasi Larutan Gula Dan Proses Pengeringan Pada Pembuatan Manisan Kering Belimbing Wuluh (Averrhoa Bilimbii). Skripsi Universitas Djuanda. Bogor.

Dharma, E. I. 2009. Dampak Manisan Terhadap Ekonomi Masyarakat Di Kabupaten Cianjur. E-Jurnal Patanjala. 4(3). 